watered. Annatto openly accomplishes the first, nature has no occasion to be ashamed of the second, nor an exhausted cow of the third.

There is reason to hope the time is not far off when it may be said of town milk-supplies that if we will only do our part in taking care of the pence, the pounds may safely be trusted to take care of themselves. And if we have no justification for the comparatively hard service still required of milk, we may at least allow it a precedent dating from a time even earlier than that at which any land can have "flowed with milk and honey."

\section{ARTIFICIAL PRODUCTION OF DIAMONDS}

GLASGOW seems determined to have the honour of producing the diamond artificially. In spite of Mr. Mactear's recent failure, Mr. J. B. Hannay, whose paper on the solubility of solids in gases we published not long ago, has been utilising the method indicated in that paper in experiments on the artificial production of the diamond. Mr. Hannay reads a paper on the subject at the Royal Society to-night, and any remarks on his work we shall postpone for the present. Meantime from the letters and articles that have appeared in the papers, we may form some idea of what has been done. Prof. Story Maskelyne, writing to the Times, says :-

"A few weelss since I had to proclaim the failure of one attempt to produce the diamond in a chemical laboratory. To-day I ask a little space in one of your columns in order to announce the entire success of such an attempt by another Glasgow gentleman. That gentleman is Mr. J. Ballantine Hannay, of Woodbourne, Helensburgh, and Sword Street, Crlasgow, a Fellow of the Chemical Society of London, who has to-day sent me some small crystallised particles presenting exactly the appearance of fragments of a broken diamond. In lustre, in a certain lamellar structure on the surfaces of cleavage, in refractive power, they accorded so closely with that mineral that it seemed hardly rash to proclaim them even at first sight to be diamond. And they satisfy the characteristic tests of that substance. Like the diamond, they are nearly inert in polarised light, and their hardness is such that they easily scored deep grooves in a polished surface of sapphire, which the diamond alone can do. I was able to measure the angle between the cleavage faces of one of them, notwithstanding that the image from one face was too incomplete for a very accurate result. But the mean of the angles so measured on the goniometer was 70 deg. 29 min., the correct angle on a crystal of the diamond being $70 \mathrm{deg}$. $317 \mathrm{~min}$. Finally one of the particles, ignited on a foil of platinum, glowed and gradually disappeared exactly as mineral diamond would do. There is no doubt whatever that Mr. Hannay has succeeded in solving this problem and removing from the science of chemistry an opprobrium so long adhering to it; for, whereas the larger part of the great volume recording the triumphs of that science is occupied by the chemistry of carbon, this element has never been crystallised by man till Mr. Hannay achieved the triumph which I have the pleasure of recording to-day. His process for effecting this transmutation, hardly less momentous to the arts than to the possessors of a wealth of jewellery, is on the eve of being announced to the Royal Society."

The Glasgow Herald, in referring to Mr. Hannay's discovery, states in a general way that his process "involves the simultaneous application of enormous pressure-probably many tons on the square inch of surface within the apparatus - and a very high temperature, ranging up to a dull red heat. It may be said that the process is the outcome of a thoroughly scientific investigation into the subject of solution, and not a 'happy-go-lucky' hit. We understand that hydrocarbon compounds have been used in the process, but we have some hesitation in concluding that the crystalline carbon is of necessity obtained by the dissociation of those compounds; by and by, however, that point will doubtless be satisfactorily established. So far as we can learn, Mr. Hannay's experiments were not all successful, there being, it is said, far more failures than successes; the latter, however, occurred near the end of the series, thus showing that the operator had become familiar with the conditions under which the dissociation of the carbon was effected, and its subsequent deposition in the crystalline form. It would seem that up to the present only very small crystalline particles have been obtained, and hence the process must be an exceedingly expensive one to produce a real gem; something like spending $5 l$. to get $5 s$., to speak roughly."

Prof. Roscoe, writing to the Times, states that the use of his name as having accepted Mr. Hannay's discovery as an accomplished fact has not been authorised by him, and that the evidence yet submitted to him by Mr. Hannay is insufficient, in his opinion, to establish so important a conclusion.

\section{THE HISTORY OF WRITING ${ }^{1}$} II.

THE new alphabet eventually made its way from the Delta to the old home of the Phœnicians on the coast of Palestine. Already in the time of David the Syrians had their historians and state annals, and Hiram of Tyre, we are told, wrote letters to King Solomon. The Phonician alphabet, as we may now call it, was communicated to the Israelites along with other elements of culture, and the neighbouring populations of Edom, of Ammon, and of Moab received it at the same time. Names had already been given to the letters, derived from Phœnician words which began with the several letters of the alphabet, $a$, for instance, being calied aleph, "an ox," b, bêth, "a house," and so on. In this way the meaning of each letter was the more easily impressed upon the memory of the Phœnician schoolboy, just as in our own nurseries it used to be thought that we should have less difficulty in learning our alphabet if we were taught that "A was an archer who shot at a frog," than if we were simply told that $A$ was $A$. Names and letters alike were imported into the countries that adjoined Phœnicia, and in course of time inscriptions in the new characters were engraved upon stone, as well as painted on the more perishable materials of papyrus or bark. The earliest monument of the Phœnician alphabet that has come down to us is the famous Moabite Stone, discovered a few years ago on the site of Dibon, which records the conquests and buildings of King Mesha, the contemporary of Ahab. The forms assumed by the characters upon this stone must have been the same as those employed by the Jewish prophets when writing down their prophecies or recording the history of their times.

Meanwhile the northern neighbours of the Phcenicians, who lived on the shores of the Gulf of Antioch, had been venturing on trading voyages into the far west and carrying with them a knowledge of the alphabet along with the wares and pottery of the East. They had found the inhabitants of Asia Minor and the adjacent islands in possession of a syllabary, the origin of which is still a puzzle, but as they pushed further westward into the islands of the Egean and the harbours of Greece, they discovered a people wholly illiterate and unacquainted even with the rudiments of picture-writing. Amongst this people whom we now term Greeks, they soon established colonies, the most important being at Thebes, and in the islands of Melos and Thera. The island of Thera was probably the first spot on European soil where words were translated into written symbols. The earliest Greek inscriptions, it is believed by competent authorities, belong to Thera, and

Lecture at the London Institution, February r2, by Prof. A. H. Sayce. Continued from p. $3^{80}$. 